\title{
The Impacts of Tsunami on the Well-Being of the Affected Community in Kuala Muda, Kedah, Malaysia
}

\author{
M. Zainora Asmawi and Aisyah Nadhrah Ibrahim
}

\begin{abstract}
The tsunami of 26 December 2004 was one of the most devastating tragedy ever occurred to men in the history of human civilization. Approximately $\mathbf{2 5 0 , 0 0 0}$ lives perished, millions injured and suffered, while the destruction of property loss of opportunities cannot be accurately estimated. The impact of the tsunami on environmental destruction shows that damage was inflicted on natural resources such as coral reefs, mangroves, sand dunes and other coastal ecosystem that acted as wave defense barriers. Moreover, inlands, wetlands and agricultural land were salinated and natural resources for livelihood and for source of income were badly affected, especially for coastal communities who were involve in fisheries. The situation worsened as basic facilities were also destroyed. As such, this research focuses on assessing and identifying on how the impacts of the tsunami on the infrastructure and environmental resources affected the community well-being inKuala Muda, Kedah, Malaysia. This study focuses on the impacts of tsunami on the affected community well-being in the coastal zone on the basis of available primary and secondary sources. Primary sources included questionnaires, interviews and observations while the secondary resources included books, government and international reports, scientific journals, maps and articles that highlighted tsunami related issues. The study tries to seek for both qualitative and quantitative impacts and also tries to find out some solutions that would help to minimize the impact of the tsunami on the community well-being. The information gained from this study can be used to help the community as well as the agencies involve in order to minimize the impacts of the tsunami on the community and develop a more effective mitigation measures for other environmental disasters such as tsunami. Besides, the research may help to create awareness on the community to be prepared in facing disastrous situation such as the tsunami. Through community preparedness, the impact can be minimized and reduced. As for the authority, this research may be of great assistance by allowing them to make better decision.
\end{abstract}

Index Terms-Tsunami, well-being, affected community, Malaysia.

\section{INTRODUCTION}

On 26th December 2004, several countries on the Indian Ocean were hit by tsunami. This phenomenon was triggered by a massive earthquake with the recorded magnitude of 9.0 on the Richter scale, with the epicenter just off the west coast of North Sumatera, Indonesia. Malaysia was affected by tsunami besides Indonesia (Aceh), Sri Lanka, Thailand, India, Maldives, Myanmar, Bangladesh, Somalia, Seychelles, Tanzania, Kenya and Yemen. Approximately 224, 685 death were reported, 174, 729 confirmed dead and 49, 956 still

Manuscript received December 20, 2012; revised January 22, 2013.

Aisyah Nadhrah Ibrahim is with International Islamic University Malaysia, Malaysia (e-mail: aisyah_ainaa@yahoo.com). missing [1]. This tsunami had claimed 68 lives in Malaysia, mostly in Penang, besides Langkawi Islands, Kota Kuala Muda,Kedah, Perak and Selangor.

\section{Problem Statements}

The impact on coastal fishing communities and the people living within the coastal areas, some of the poorest in the region has been devastating with high losses of income earners as well as boats and fishing gear[2]. The disaster devastated communities with its high toll of human lives, injuries, family networks, homes and livelihoods. The majority of those affected on the coast were fishermen who suffered the most damage in terms of housing and livelihoods with loss of dwelling units, household assets, and productive assets like boats and nets. This situation also happened in Kuala Muda whereby the affected fishing villagers lost most of their valuable belongings including lives.

A World Health Organization (WHO) funded a study by the University of Indonesia reported that $20-25 \%$ of children affected by the tsunami in Aceh required professional treatment for psychosocial problems. Additionally, a dramatic increase in the demand for counseling and psychological cares, including tertiary-referral specialized care, was registered in the entire country. Not all these were people who had been directly affected; some were people in nearby areas who vicariously shared the trauma of the tsunami and worried about the possibility of new waves.

\section{GOAL AND OBJECTIVES}

The goal of this study is to understand and to analyse the impacts of tsunami towards the well-being of the affected community. These are the objectives of the study in order to achieve the goal:

1) To describe the existing condition of the coastal environment; and

2) To identify the impacts of the tsunami on community well-being in terms of physical infrastructure, and environmental aspects.

\section{SCOPE OF STUDY}

Based on Table I below, the scope for this study can be divided into two sections. The first section covers the perception of the community on tsunami. The scope under this part addresses the general knowledge of the community on tsunami. The second part discusses about the impact of the tsunami on the community well-being. 


\section{Research Methodology}

The study was conducted on 211 people from Kota Kuala Muda,Kedah. Observations and questionnaire survey were the main tools in conducting this study. The questions that were asked in the survey were not only limited to the people who are directly affected by the tsunami but also to the surrounding communities who are also indirectly affected by the event.

TABLE I: THE SCOPE OF STUDY

\begin{tabular}{|c|c|}
\hline Scope & Description \\
\hline $\begin{array}{l}\text { Perception of the } \\
\text { community on } \\
\text { tsunami }\end{array}$ & $\begin{array}{l}\text { - Coastal hazards which are prone to Malaysia } \\
\text { - Awareness on the early warning system on } \\
\text { tsunami } \\
\text { - Their opinion on the factors which can lead to } \\
\text { tsunami. }\end{array}$ \\
\hline $\begin{array}{l}\text { Impact of tsunami } \\
\text { on the community } \\
\text { well-being. }\end{array}$ & 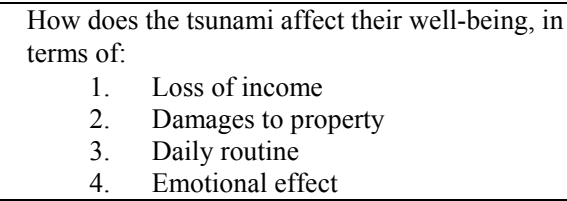 \\
\hline
\end{tabular}

The main tools ofdata collection in conducting the study were observation and self-administered questionnaire, containing closed-ended and open-ended questions.The questionnaireswere divided into four sections. The first section is related to the respondents' profiles. The second section covered the existing condition of Kuala Muda coastal area and the third section was directed to the impacts of tsunami on the community well-being.

The Likert scale measurement was used for every statement for the environmental issues on a 5 point scale. Each alternative item was assigned from 1 (strongly agreed), 2 (agreed), 3 (undecided), 4 (disagreed) 5 (strongly disagreed) for favorable items. Thiswould enable the respondents to rate each and every variables based on their personal level of concerned.

Scoring system subsequently was employed in the research in order to identify the variables with higher and lower weighted scoring, and the pre-determined items were arranged accordingly to priority. This was done by allocating numeric value to the options, for example, if the respondents chose the option as the first choice they would be scored 4 , second choice as 3 , third choice as 2 and forth choice as 1 and the last choice as 0 mark. Then, all the data were keyed in SPSS software for analytical process.

\section{ANALYSIS AND FINDINGS}

\section{A. Observation on the Existing Condition of Luala Muda, Kedah.}

From the site visit which have been carried out, the existing condition of the coastal area of Kuala Muda can be described as the following. There were eight villages which have been visited and it have been categorized into 5 sections (Fig 1). The selected eight villages referring to the ones which have been badly hit directly by the tsunami on the $26^{\text {th }}$ December 2004. Section 1 (M1) consists of Kg. Pulau Sayak, Section 2 (M2) consists of Kg Sungai Yu and Kg Sungai Meriam, Section 3 (M3) consists of Kg. Paya, Setion 4 (M4) consists of $\mathrm{Kg}$ Padang Salim and Section 5 (M5) consists of
Kg Masjid, Kg Tepi Sungai and Kg Kepala Jalan.

M1: Kg. PulauSayak

$\mathrm{Kg}$. PulauSayak was the least affected area of the stretch of Kuala Muda coastal area. Most of the fringes along PulauSayak were full of mangrove forest. This is also one of the main reasons why Kg PulauSayak was the least damaged area when the tsunami occurred. The mangrove acted as a natural wave breaker for that coast area. Besides, there was only a small population which lives in $\mathrm{Kg}$. PulauSayak which mostly earns their living as fishermen.

M2: Kg. Sungai Yu and Kg. Sungai Meriam

$\mathrm{Kg}$ Sungai $\mathrm{Yu}$ and $\mathrm{Kg}$ Sungai Meriam are located right next to each other. The villagers that lived in this area were mostly involved in agricultural activities but in a small scale or for family basis such as coconut and bananas. There was also a small factory running there for livestock such as chickens and ducks. The area that was affected or damaged by the tsunami was rather a small portion of this. Mostly the affected areas were the residential areas which now have been repaired back with the donations, funds and aids given by the national bodies and several others local Non-Governmental Organization (NGOs).

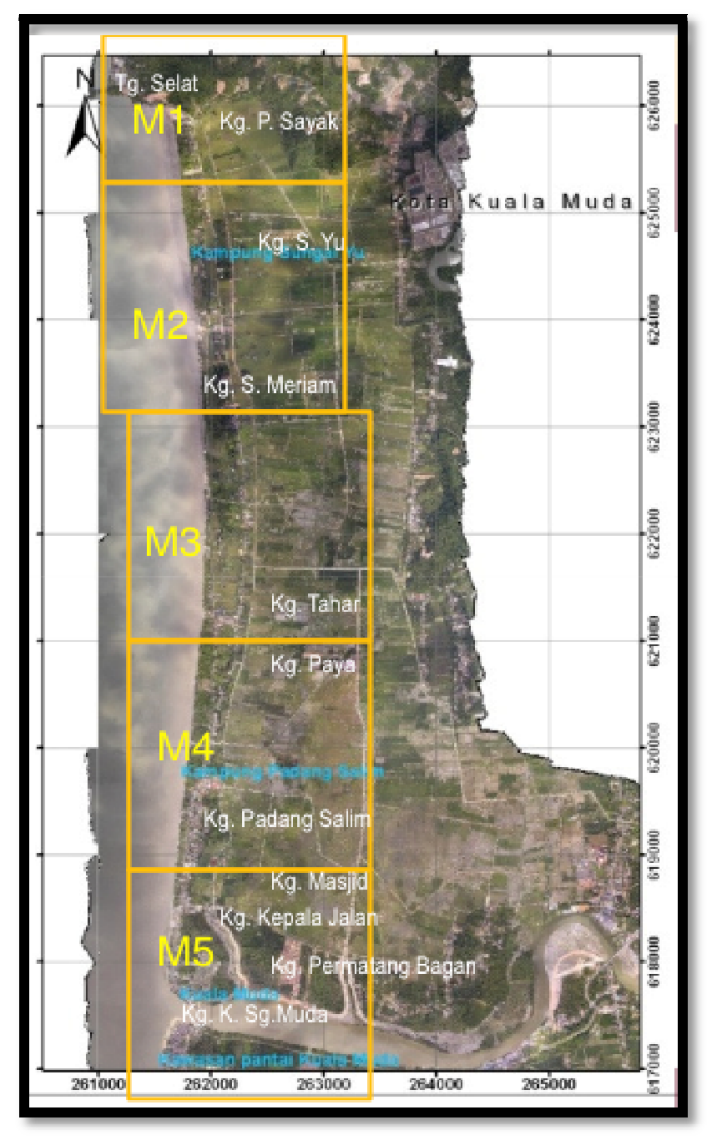

Fig. 1. Sections of study area

M3: Kg. Payaand M4: Kg. Padang Salim

$\mathrm{Kg}$ Paya and $\mathrm{Kg}$ Padang Salim areas were moderately damaged by the tsunami event. This was due to its distance that located very near to $\mathrm{Kg}$ Masjid and $\mathrm{Kg}$ Tepi Sungai, which were badly damaged by the tsunami. Most of the damaged areas were residential areas. There were a few houses, badly damaged and could not be repaired. But there were also a few of the houses which their structures were still intact and were restored back. There was not much of 
infrastructure damage such as at the roads. According to the villages, the roads were covered with mud that was wiped ashore by the strong wave. But they managed to clean up the road areas with the help from the various volunteer bodies.

M5: Kg. Masjidand Kg. TepiSungai

$\mathrm{Kg}$ Masjid and Kg Tepi Sungai were badly damaged by the tsunami during the event. Most of the houses that were located 10-20m away from the beach were badly damaged. They were approximately 100 houses located along the coast of $\mathrm{Kg}$ masjid and $\mathrm{Kg}$ Tepi Sungai but after the tsunami, there are only about 4-10 houses left. The representative of the villagers made an effort to build a mini museum of remembrance for the event itself. The museum is located just $20 \mathrm{~m}$ from the beach and they used the remnant of the houses that were damaged by the tsunami to be included in the museum. Moreover, they piled up the fishing boats to become a statue of remembrance and also have become a landmark for the area.

There are currently several projects such rock revetment to protect the coast from the waves. The brick were being put along the shoreline from $\mathrm{Kg}$ Sungai Muda until up to $\mathrm{Kg}$. Masjid. Besides that, there is also a greeneries plantation project along the coast. This shows that some mitigation measures were being taken in order to minimize the impacts of tsunami towards the community.

Observation indicated that most of the villages located along the coast were severely affected by the tsunami event. Most of the damages were towards their properties such as the house, motor vehicles, fishing boats and equipment and shop houses (Fig. 2). Other damages included the paddy field located around $150 \mathrm{~m}$ from the coastal areas and the road infrastructures near the coastal areas.

The state council has built a low cost residential area just to cater the tsunami victim which is located just $300 \mathrm{~m}$ from the beach. The residential area is called Taman PermatangKatong. The area was formerly forested areas that were transformed into a residential area to cater the needs of the affected community of the tsunami occurrence. There are approximately 126 houses in the residential area which mostly are owned by families. The residential areas were equipped with basic facilities and utilities such as a surau, a playground and a multipurpose hall.

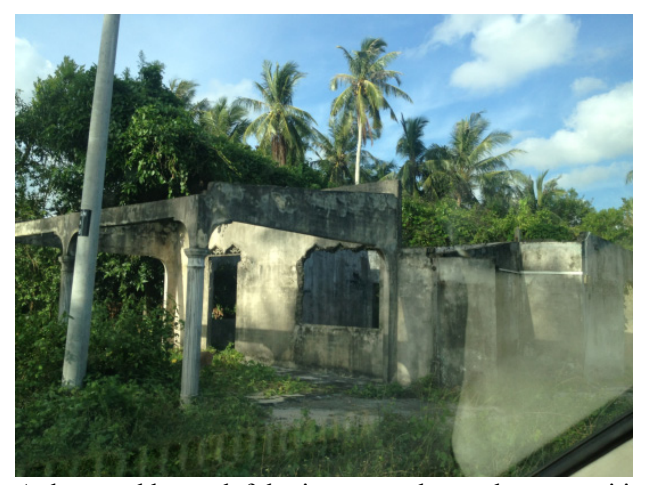

Fig. 2. A damaged house left by its owner due to the tsunami impact.

\section{B. Impact of Tsunami on the Well-Being of the Community from the Community Perspectives.}

Table II shows the results of the questionnaire survey on the impacts of tsunami on the well-being of the community. The impacts were divided into four parts which are loss of income,damage to properties, effect of daily routine and emotional effects.

TABLE II: THE IMPACTS OF TSUNAMI ON THE WELL-BEING OF THE COMMUNITY

\section{IMPACTS}

TOTAL AVER.SUM

\begin{tabular}{|c|c|c|}
\hline \multicolumn{3}{|l|}{ 1. LOSS OF INCOME } \\
\hline $\begin{array}{l}\text { - Decrease in daily and monthly catch due to } \\
\text { the destruction of marine life and vegetation. }\end{array}$ & 503 & 2.62 \\
\hline $\begin{array}{l}\text { - Damage to farms and agriculture areas which } \\
\text { affect the livestock and other agriculture } \\
\text { production }\end{array}$ & 517 & 2.69 \\
\hline $\begin{array}{l}\text { Damage to fishing equipment which causing } \\
\text { disturbance to fishing related activities. }\end{array}$ & 677 & 3.21 \\
\hline $\begin{array}{l}\text { Damage to infrastructures and } \\
\text { telecommunications such as roads, telephone } \\
\text { lines and networks, which causes businesses } \\
\text { to have come to a halt. }\end{array}$ & 629 & 2.98 \\
\hline \multicolumn{3}{|l|}{ 2. DAMAGE TO PROPERTIES } \\
\hline - Damage to houses & 666 & 3.16 \\
\hline $\begin{array}{l}\text { - Damage to fishing equipment such as boats } \\
\text { and large fish nets. }\end{array}$ & 560 & 2.65 \\
\hline - Damage to farms and agriculture areas & 384 & 1.82 \\
\hline $\begin{array}{l}\text { - Damages to underground piping systems and } \\
\text { electrical networks. }\end{array}$ & 606 & 2.87 \\
\hline \multicolumn{3}{|l|}{ 3. EFFECT DAILY ROUTINE } \\
\hline $\begin{array}{l}\text { Disturbance to schooling sessions due to } \\
\text { damages to school equipment and properties. }\end{array}$ & 682 & 3.23 \\
\hline $\begin{array}{l}\text { - Damages to motor vehicles that is the main } \\
\text { transportation to get from one place to } \\
\text { another. }\end{array}$ & 673 & 3.19 \\
\hline $\begin{array}{l}\text { Effect food supply sources due to damages to } \\
\text { shop houses, decrease in catches (fishes, } \\
\text { crabs, prawns and others), loss of farms and } \\
\text { other agriculture areas). }\end{array}$ & 384 & 1.82 \\
\hline $\begin{array}{l}\text { - Loss connection to other places due to } \\
\text { damages to infrastructure such as road. }\end{array}$ & 393 & 1.86 \\
\hline \multicolumn{3}{|l|}{ 4. EMOTIONAL EFFECTS (TRAUMA) } \\
\hline $\begin{array}{l}\text { - Trauma of actually witnessing and } \\
\text { experiencing the event }\end{array}$ & 544 & 2.57 \\
\hline $\begin{array}{l}\text { - Loss of family members and friends due to } \\
\text { the tsunami }\end{array}$ & 323 & 1.53 \\
\hline - Serious injuries due to the event & 373 & 1.77 \\
\hline
\end{tabular}

From the table above, it reflects the impacts faced by the affected community at the study area. For the first category, which is loss of income, most of the respondents responded that the major cause of the tsunami is damage to their fishing equipment which causing disturbance to fishing related activities. Most of the fishing boats and fishing equipment, such as fish pots and dragnets were left or stored near the Sungai Muda river mouth jetty [3]. This impact has the highest weighted score in the loss of income category with the weighted score of 677. Moreover, according to a newspaper article issued by the Star, 2004, most of the villages affected were fishing villages and most of the populations on the coastal area earn their living through fishing activities. Next, the second highest weighted score with 629 was the damage to infrastructures and telecommunications such as roads, telephone lines and networks, which causes businesses to have come to a halt. Next in the loss of income category is due to the damage to farms and agriculture areas, which affected the livestock and other agriculture production with 517 weighted score and the least response was referring to decrease in daily and monthly 
catch due to the destruction of marine life and vegetation with the weighted score of 503 .

The second category is the damage to properties. With the highest weighted score of 666, the respondents agreed that the tsunami has caused damage to properties but mostly to their houses. This result were in line with other scholars which stated that the coastlines of many countries face high risks of damage from certain types of natural disasters [4]. The major concern is death and property loss. The second one is damages to underground piping systems and electrical networks with the weighted score of 606 . According to the interview done with the representative of the villagers HjYusufAwang (2012), most of the areas along the coastal area experienced an electrical and water shortage for about a week after the tsunami event. This is due to the damage to the electrical system and underground water piping system. The third one is damage to fishing equipment such as boats and large fish nets with the score of 560 and the last one is damage to farms and agriculture areas with the weighted score of 384. This is because, as a result of the tsunami disaster, the paddy fields were contaminated with salt water [5].

The next category is that due to the tsunami, it affected the community daily routine, most of the respondents stated that because of the tsunami, it has caused disturbance to schooling sessions due to damages to school equipment and properties with the highest weighted score of 682 . This is because, due to the tsunami the school which were located nearer to the coast was badly damaged in terms of school properties while the schools located in the adjacent areas were being used as the temporary home for the tsunami victims. The schools included were Sekolah Kebangsaan Haji Sulaiman and Sekolah Kebangsaan Kota Kuala Muda. The next highest is the damages to motor vehicles that was the main transportation to get from one place to another with the weighted score of 673. Next is loss connection to other places due to damages to infrastructure such as road with the score of 393 and the least is the tsunami affect food supply sources due to damages to shop houses, decrease in catches (fishes, crabs, prawns and others), loss of farms and other agriculture areas).

The last category is the emotional effect cause by the tsunami. Most of the respondents agreed that because of the tsunami, they experienced trauma of actually witnessing and experiencing the event. This has the highest weighted score of 544.Some of the villagers who were formerly work as fishermen quit their job and now work as farmers or construction workers because they are afraid to go back to the sea. Next is injury sustained by the villages due to the tsunami with the score weight age of 373 . The injuries included wounds, broken and fractured limbs and other injuries.

\section{Tools to Minimize the Impact of Tsunami on the Community Well-Being.}

Table III indicates the tools which could be used in order to minimize the impact of tsunami according to the local community of Kuala Muda. Based on the score, it shows that most of the residents agreed that by increasing the hazard and disaster awareness among the community could minimize the impact of a certain disaster with a score of 801 . Many researchers also agree that by educating the public about the tsunami hazard, communities become informed and empowered to take actions that prepare them for tsunamis or other disaster. People are taught to recognize the warning signs of an impending tsunami and take action towards it.

TABLE III: TOOLS TO MINIMIZE THE TSUNAMI IMPACTS ON THE COMMUNITY WELL-BEING

\begin{tabular}{lll}
\hline \multicolumn{3}{c}{ COMMUNITY WELL-BEING } \\
Tools & Total & $\begin{array}{l}\text { Ave. } \\
\text { sum }\end{array}$ \\
\hline $\begin{array}{l}\text { a. Tsunami warning system } \\
\text { b. Planting greens and environmental } \\
\text { preservation }\end{array}$ & 717 & 3.4 \\
\hline $\begin{array}{l}\text { c. Increase hazard and disaster awareness among } \\
\text { the community }\end{array}$ & 801 & 3.6 \\
\hline $\begin{array}{l}\text { d. Building coastal structures such as seawalls } \\
\text { and breakwaters }\end{array}$ & 675 & 3.2 \\
\hline \hline
\end{tabular}

The second highest tool that is agreed by the respondents to minimize the impact of tsunami is by planting more greens and preservation of the environment. This carries the score of 759. [6]also state that apart from the distance of the houses from the shoreline, the degree of destruction on homes was also dependent on several other factors including extent of frontal protection provide by other buildings, strength of house structure and existence of wave protectors such as tree clusters and etc.

Next is the tsunami warning system with the score of 717. According to the Malaysian Ministry of Science, Technology, and Innovation, Malaysia has established the Malaysia National Early Tsunami Warning System in 2005 to provide early warning on tsunami generated by the Indian Ocean, South China Sea and the Pacific Ocean that may affect Malaysia. There are currently 17 seismic stations located around Malaysia offshore and around 20 more in the international waters. This shows that Malaysia has taken a more serious action towards minimizing the impact of tsunami on the community.

The most common type of protection for property along coast is within the spectrum of structures that are designed to protect and stabilizes the coast [7]. This general procedure is typically referred to as hardening the coast [4]. Subsequently, the respondents respond least to building coastal structures such as breakwaters and seawalls in order to minimize the impact of tsunami on the community well-being with the score of 675 . The result also shows that jetties, groins, and breakwaters hinder sediments that would normally collect along the shoreline. Seawalls, revetments and bulkheads also contribute to the hindrance of sediments normal patterns of distribution and thus cause erosion.

Table IV indicates the opinion of the community in Kuala Muda, Kedah on what to improve in order to enhance the services and public response. Referring to the table, it shows that most of the respondents opted for better telecommunication and more accurate warning with the weighted score of 801 for both. This also requires for close collaboration among institutions and organizations of several countries is needed for rapid exchange of data and warnings and to maintain the seismic and ocean observing systems. 
TABLE IV: COMMUNITY'S PERCEPTION ON WAYS TO IMPROVE SERVICES AND PUBLIC RESPONSES

\begin{tabular}{|c|c|c|}
\hline Types of actions & Total & $\begin{array}{l}\text { Ave. } \\
\text { sum }\end{array}$ \\
\hline a. Greater availability of data & 718 & 3.4 \\
\hline b. Better telecommunication & 801 & 3.8 \\
\hline c. More accurate warnings & 801 & 3.8 \\
\hline d. Better dissemination & 759 & 3.6 \\
\hline e. Enhance the awareness risk & 715 & 3.4 \\
\hline $\begin{array}{l}\text { f. Enhance public education to understand and } \\
\text { respond to warnings. }\end{array}$ & 737 & 3.5 \\
\hline $\begin{array}{l}\text { g. More effective decision making within } \\
\text { government }\end{array}$ & 760 & 3.6 \\
\hline
\end{tabular}

Next is more effective decision making within government and better dissemination with the score of 760 and 759 . Government needs to regulate strategic policies and strategic action plans in order to regulate and encourage participatory approach in development activities in vulnerable areas. Besides that, they also should include seismic and other related geo-hazards into development process. But this statement can be strongly disagreed. This is because, according to a risk study done by Ministry of Science, Technology and Innovation (MOSTI) in 2009, it has been found out Malaysia is one of the country which have a chain of agencies which are responsible for managing seismic and tsunami hazards.

\section{CONCLUSION}

The occurrence of tsunami in Malaysia generally affected the people, particularly the community living at the coastal areas. Kuala Muda in the state of Kedah located at the northern Peninsular Malaysia was amongst the areas that were badly hit by the tsunami. Thus, this research was conducted to get the perceptions of the affected community related to the impacts of tsunami. Majority of the respondents said that the areas that were mostly affected related to the damage of properties, i.e. houses and loss of income. This was eventually affected their daily routine and lifestyle. Taking this painful experience as a lesson, they felt that to handle such occurrence of event, the community at large need to increase the awareness level on the natural disasters, so that the preparedness is taken care of by all stakeholders to minimize the disastrous impacts. It is wished that this research could contribute to increasing the value of understanding the nature by addressing the perceptions of the affected community.

\section{REFERENCES}

[1] Tsunami Mitigation Strategies, Tsunami Awareness Kit, Pacific Disaster Centre, 2005.

[2] L. Lycnh, "Reducing tsunami risk in the eastern carribeen," Seismic Research Unit. The University of the West Indies, 2007.

[3] I. Komoo and M. Othman, "Bencana tsunami 26.12.04 dimalaysia: kajian impak alam sekitar, sosio-ekonomidan kesejahteraan masyarakat," Institut Alam Sekitardan Pembangunan (LESTARI). Bangi, Selangor, 2005.

[4] R. D. Jr. and D. Fitzgerald, Beaches and Coasts, Maleden, MA: Blackwell Publication, 2004.

[5] F. Danielsen, M. K. Sorensen, M. F. Olwig et al., "Coastal vegetation and the Asian tsunami," Reply Science, vol. 311, pp. 36-37, 2006.

[6] F. W. Colbourne, "Tsunami impact on the west coast of penang island, malaysia," Project for the Master of Science Degree, Earth Science Department, Emporia State University, Emporia, Kansas, USA, 2005.

[7] R. Y. Hudson, "Design of quarrystone cover layers for rubble- mound breakwaters," Research, U. S. Army Engineer Water- ways Experiment Station, CE, Vicksburg, MS, no 2-2, 1958.

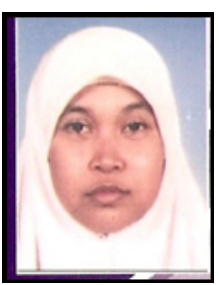

M. Zainora Asmawi was born in 1970 9n Kuala Lumpur, Malaysia. She obtained her bachelor degree in the field of urban and regional planning from Technology University of Malaysia. She has a Master of Environment from Putra University of Malaysia and she pursued her $\mathrm{PhD}$ in coastal planning and management from the University of Portsmouth, United Kingdom.

She has produced several publications. She has involved in many urban planning studies and works but her interests in environmental studies.

Dr Asmawi is a corporate town planner registered with the Malaysian Institute of Planners and Board of Town Planners, Malaysia. At a local level, her research work has won a gold medal in the IIUM Research Invention, Innovation and Exhibition (IRIIE) 2011. She also had won a silver medal and a bronze medal in the same event in 2010 and 2009 respectively.

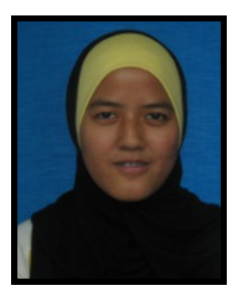

Aisyah Nadhrah Ibrahim was born in Kuala Lumpur Malaysia in 1988. She currently holds a bachelor degree in Urban and Regional Planning from the International Islamic University Malaysia in 2010. She is currently pursuing her master in Built Environment at the same university with the interest in the environmental studies. She has presented several papers at the national and international level on the subject of environmental aspects. 